\title{
Run Errand
}

National Cancer Institute

\section{Source}

National Cancer Institute. Run Errand. NCI Thesaurus. Code C95549.

To make a short trip for a particular purpose, especially to buy or deliver something. 